\title{
On the Way to a Good Man Again-An Analysis of Amir in The Kite Runner from Perspective of Freud's Personality Structure Theory
}

\author{
Ting Wen \\ College of Foreign Studies, Nanjing Agricultural University, Nanjing, China
}

\begin{abstract}
The Kite Runner is the first novel that was written by Afghan-American writer Khaled Hosseini. This novel tells the story of an Afghan immigrant boy called Amir in the United States and his spiritual redemption of his fault made during his childhood, using the first-person perspective. This thesis attempts to analyze Amir's triple personality thoroughly: id, ego and superego from Freud's personality structure theory, making readers have a deep understanding of how Amir lost, how to form the powerful self, and finally to complete the sublimation of his personality to be a good man. Meanwhile it aims to analyze how Amir forms his own ego.
\end{abstract}

Index Terms - The Kite Runner, Amir, personality structure

\section{INTRODUCTION TO THE WORK}

The Kite Runner is the first novel that was written by Khaled Hosseini who is an Afghan-American author, which was published in 2003. Soon after that, it ranked as a top one New York Times bestseller, with more than seven million copies sold in America, over twenty million copies around the global. Moreover, it has been translated into forty-two languages all around the world. This work mainly tells the story of Amir, a young boy from Kabul, Afghanistan. One day Hassan, Amir's close friend as well as his home servant, suffers an act of violence from a few local bad guys, while young Amir fails to prevent it due to his selfishness and cowardice. Then, Amir's guilt can not be relieved, and he chooses to charge Hassan with stealing his valuable present in front of his father and drive Hassan away from his home. Afterwards, grown-up Amir lives in pain and guilt in America, but he still dare not face the past when he did harm to innocent Hassan. Not until the truth comes eventually does he attempt to make amends for his fault by going back to his hometown and rescuing Hassan's son in the war-stricken Afghanistan without any doubt and fear.

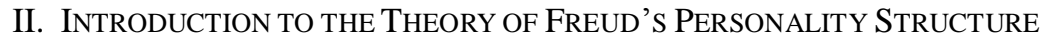

Sigmund Freud, an Austrian neurologist and the founder of psychoanalysis, developed a model of personality structure, comprising the following three parts "id, ego and super-ego". As Freud (1933) described the relationship among these three components of human's personality structure that the id is related with the trends which are uncoordinated instinctual set. Then in people's daily life, the super-ego plays a critical and moralizing part. The ego is an organized, realistic part, balancing the desires between the id and the super-ego in people's inner heart. Thus, We may conclude from his description that these three components in a state of harmonious balance that make one's personality sound. Otherwise, the disorder among them will threaten the normal development of one's personality.

In one interview, Khaled Hosseini(2007) once presented his personal view on this story he wrote: "As a writer, I hope that the reader can find what he or she is looking for when reading a novel: moving stories, participating characters, feelings of loss, changed by the experience of the characters. I want the reader to react to the emotion of the story especially." (P.9)Therefore, Amir, as a protagonist in The Kite Runner, whose id, ego, superego vividly presented in the whole story that can be deeply analyzed from the perspective of Freud's personality structure. By analyzing the three elements of the protagonist's personality in the novel, this paper helps readers to get across the psychological factors of the protagonist's personality in the novel from a broader view, and provide readers with a new perspective of the interpretation of this literary work.

\section{An Analysis of Amir From the PersPective of FreUd’s Personality Structure}

\section{A. The Id: Amir Is on the Way to Sin}

As far as Amir's father concerned, Amir is coward, lacking the ability of self-defense and prefers burying his head in books to doing sports vigorously as his father's wish. To Amir's jealousy, Amir's father cares more about Hassan, the son of their servant, than his own son. The young Amir never seems to live up to his father's expectation which makes Amir feel he is a kid without the care from his father. But Hassan's courageous character and performance always wins his father's praise. Based on Freud's theory of psychology, Calvin Springer Hall (1987) once explained his opinion on 
children's admire for parents' love as follows, "The Loss of their identification is commonly suffered among children who are coldly treated by their parents. In order to regain their parents' love, they try their most effort to act according to their parents' will."(P.75) That Amir's mother died when he was born makes Amir enjoys no maternal love. Amir's father is declared sole guardian to Amir later. Thus it makes him crave fatherhood and hope to gain his father's approval through his own efforts. Under such circumstance, the id drives Amir to hate Hassan, desire more parental love. Then the opportunity for Amir to earn his father's affection comes: the winter traditional kite-fighting tournament will be held, whose rules are flying your kites, cutting the opponents, running for the last cut kite. As expected, Amir wins by cutting all opponents' kites. Hassan as Amir's assistant, cups his hands around his mouth to Amir before he runs the falling blue kite for Amir: 'For you a thousand times over!' he said. Then he smiled to his Hassan and disappeared around the corner."(Hosseini, 2003, P.73) On his way home with the found falling kite, Hassan is raped violently by Assef, a young bully, for Hassan refuses to hand this kite into him. However, Amir only watches the violence suffered on Hassan in the darkness without standing up to rescue the poor lamb, Hassan.

"I had one last chance to make a decision. One final opportunity to decide who I was going to be. I could step into that alley, stand up for Hassan - the way he'd stood up for me all those times in the past-and accept whatever would happen to me. Or I could run.

In the end, I ran.

I run because I was a coward. I was afraid of Assef and what he would do to me... That's what I made myself believe. I actually aspired to cowardice, because the alternative, the real reason I was running, was Assef was right: Nothing was free in this world. Maybe Hassan was the price I had to pay, the lamb I have to slay, to win Baba. Was it a fair price? The answer floated to my conscious mind before I could thwart it: He was just a Hazara, wasn't he?" (Hosseini, 2003,P.84-85)

According to Freud, the id is unconscious by definition: "It is the dark, inaccessible part of our personality. We approach the id with analogies: we call it a chaos, a cauldron full of seething excitations. ...It is filled with energy reaching it from the instincts, but it has no organization, produces no collective will, but only a striving to bring about the satisfaction of the instinctual needs subject to the observance of the pleasure principle." (Freud,1933,P.105-106) With regard to the pleasure principle, as an American psychologist, Charles R. Snyder (2007) depicted it that the reason why people have a tendency to pursue the pleasing pleasure and get away from suffering pains and sorrows is that they desire to satisfy biological and psychological needs.

At that moment, there is a fierce struggle between the id and the super ego in the mind of Amir. During the process of struggle, the superego tends to be vulnerable, while the id dominates young Amir, instigating him to commit a crime to meet his psychological needs. Confronted with danger and interest, Amir chooses to keep silent and betray Hassan in exchange of his father's love and appreciation, which turns out that Amir is a selfish, coward and even despicable boy controlled by the id. Amir loses himself in the only quest for recognition and emotional love from his father. Thus, Hassan is forced to be a victim to satisfy Amir's selfness. Hassan spends most of his life in compromising with the surrounding environment, and his self-expression is dominant. This compromise preserves his living space in the Amir's family, but it depresses himself deeply without any abreact. However, Amir's heart will be tormented by the chosen selfish choice in the future. As a result, Amir is on the way to sin virtually.

\section{B. The Super Ego: Amir Is on the Way to Awareness}

As Snowden Ruth(2006), who has strong interest in the psychological works of Freud and makes some contribution in studying this academic area at the University of Birmingham, expressed the opinion that: "The super-ego aims for perfection. The super-ego works in contradiction to the id, striving to act in a socially appropriate manner. The super-ego controls our sense of right and wrong and guilt. It helps us fit into society by getting us to act in socially acceptable ways." (P.105-107)

Hassan is a servant in Amir's family, but he appears as a perfect image, not including his physical defect, harelip. As described in the work, "Hassan was true to his nature. He was incapable of hurting anyone." (Hosseini, 2003, P.11) Hassan chooses to forgive, even after Amir hurts him on purpose. Zheng Suhua (2015) pointed out "Hassan is a master of kite chaser. In the novel, kites symbolize the purity of human nature. The reason why Hassan is able to catch a kite every time is because he possesses the purest quality of human beings. Then, he never loses his way in chasing the kite of life and his daily life."(P.75) What moves readers deeply is the words he says to Amir: "For you a thousand times over!" In the novel, Hassan makes a weird dream. "We were at Ghargha Lake, you, me, Father, Agha sahib, Rahim Khan, and thousands of other people. It was warm and sunny, and the lake was clear like a mirror. But no one was swimming because they said a monster had come to the lake. It was swimming at the bottom, waiting."(Hosseini, 2003, P.65) The image of monster shows up in Hassan's dream, what does it present? Freud applied other writers' opinion to show the relationship of dreams to walking life, as "for apparently it can often be observed in great majority of dreams that, rather than freeing us from ordinary life, they lead us right back into it...... The content of dreams is always more or less determined by the individual personality, by age, sex, class, level of education, mode of life and by all the events and experiences of our lives hitherto."(Freud, 1999, P.10) Thus, we may infer that the showing up of the monster does exist in Hassan's real life, no matter the gangs, Amir or Amir's father.

More or less, those people like everywhere monsters actually have done harm to Hassan now and then. That is why the monster shows up in Hassan's dream rather than in others'. However, in Hassan's personality structure, the needs of 
the id are ruthlessly crushed by the superego in his inner heart world and the outside world, and his ego obeys the rules created by superego unconditionally, so Hassan who is dominated by super-ego following Amir with faithfulness, defending Amir with courage, which influences Amir thoroughly and makes Amir's soul redeemed as well. In other word, it is Hassan who has crucial influence on Amir's later change in thoughts and actions as a good man.

Amir's father is also portrayed as a perfect and epic image, a typical Pashtun (an ethnic group from Afghanistan and Pakistan), who is physically strong and charismatic, impossible to ignore in the crowd. He is one of the richest merchants in Kabul, who donates large amount of money to build orphanages, schools for local kids and help people in need. "Now, no matter what the mullah teaches, there is only one sin, only one. And that is theft. Every other sin is a vibration of theft. Do you understand? When you kill a man, you steal a life. You steal his wife's right to a husband; rob his children of a father. When you tell a lie, you steal someone's right to the truth. When you cheat, you steal the right to fairness. Do you see? There is no more wretched than stealing, Amir. A man who takes what's not his to take, be it a life or a loaf of naan... I spit on such a man. And if I ever cross paths with him, God helps him. Do you understand?" (Hosseini, 2003, P.19-20) As cited above, to his father, the act of theft is the most heinous sin, which Amir agrees with from the depth of his heart full of the pure adoration and admiration. It is Hassan and Amir's father as shaped images without any flaws controlled by super-ego that awakens Amir's awareness to pursue his own super-ego.

\section{The Ego: Amir Is on the Way to Redemption}

In accordance with the reality principle, the ego aims to follow the id's drive in realistic ways. The purpose of it is to benefit themselves in the long term rather than bringing grief in the short term. The task of it is to seek a balance between the realities happened in daily life and the primitive drives or desires while satisfying the id and super-ego at the same time. Freud (1933) conceded that the ego is driven by the ego, as well as restricted by the super-ego. While, it may be turned down by reality, striving to bring about related harmony among the forces and influences which are caused by reality. Meanwhile the ego breaks out in anxiety with realistic anxiety concerning the external world, moral anxiety upon the super-ego, neurotic anxiety about the force of the passions that implanted in the id readily.

How does Amir's ego form?

First of all, Amir is a child whose conscience never fades out. The inner growth of Amir as the protagonist deserves our deep consideration. Behind the external growth of him in the novel is the growth process which is from innocence to betrayal, then from inner confession to final redemption. After teasing or playing tricks on Hassan, Amir always feels guilty about it. Therefore he gives Hassan old shirts or broken toys, which he supposes it may make up for a harmless prank. Besides, during his adult period, despite of his wife's infertility, Amir refuses to adopt any children with the following reason, "Perhaps something, someone, somewhere, had decided to deny me fatherhood for the things I had done. Maybe this was my punishment, and perhaps justly so. It wasn't meant to be, Khala Jamila had said. Or maybe, it was meant not to be." (Hosseini, 2003, P.204) Amir even regards this incident as a punishment for his unforgivable fault made against Hassan, living in pain and remorse all the time, which promotes the awakening of his ego gradually.

In addition to the internal factor, Rahim Khan, as a best friend of Amir's father, acts as a mentor, playing a vital role on Amir's way to redemption. In Amir's childhood, Rahim Khan always plays the role of Amir's father mentally, supporting and encouraging Amir, leading Amir to pursue ego by overcoming the suppression of id, which is a way to be a good boy as expected. "On his way out, Rahim Khan hunkered before me and handed me my story and another folded piece of paper. He flashed a smile and winked. 'For you. Read it later.' Then he paused and added a single word that did more to encourage me to pursue writing than any compliment any editor has ever paid me. That word was Bravo." (Hosseini, 2003, P.35) While in Amir's adulthood, he leads a satisfying and peaceful life in America, which is disturbed by a call form Rahim Khan, saying: "Come, there is a way to be good." (Hosseini, 2003, P.207) Thus, his id and super ego has a fierce struggle, before he determines to go back to his hometown. Amir is driven by the id he should enjoy current peaceful life, the happy marriage, the prosperous career in America. Meanwhile, he is driven by the super-ego he should not behave as an ostrich burying his head in the sand anymore and he should go down the path of being a good man to face his fault made before bravely. Eventually, his super-ego succeeds in making him act by his appearing ego.

What's more, it's commonly accepted that men have absolute control over marriage and property in Afghanistan. Kate Millet (2000) expressed that this determines the position of men within and outside the family is both material and ideologically sound. Under the influence of Afghan traditional culture and religion, men hold the absolute right to speak in family life, and the role of father is also shaped by the image of majesty, tallness and bravery to win the adoration and admiration of children. In this novel, the patriarchal representative of male supremacy is the father of Amir in the upper class. Therefore Amir reveres and worships his father, tends to be dependent on his father. After meeting Rahim Khan in Kabul, Amir knows the truth Hassan is his illegitimate half brother which is a shock for Amir. Amir's father has an affair with the wife of Ali, his servant, making her give birth to Hassan. In accordance with the theory of theft proposed by himself, his father can be called a theft, stealing Amir and Hassan's right to the truth to preserve his own dignity. Several years later, his father with Amir flees to the United States and starts a new life because of the war. As his father is busy in supporting his family to cultivate Amir in terms of academic study and daily life, having more opportunities to care about Amir's feelings with parental love that Amir used to desire. Naturally, the relationship between the father and son is well developed. Amir's character is fully developed in the process which makes Amir admire his father more and more from his own heart. However, the father passes away with the secret story of his life without admitting that he 
did harm to others before to his son. When he was young, he made a terrible mistake controlled by his own id, causing the tragedy of Hassan's whole life and leaving himself regretful for the rest of his life. "How could he have lied to me all those words? To Hassan? He has sat me on his lap when I was little, looked me straight in the eyes, and said, There is only one sin. And that is theft... When you tell a lie, you steal someone's right to the truth. Hadn't he said those words to me? And now, fifteen years later I'd buried him, I was learning that Baba had been a thief. And a thief of the worst kind, because the things he'd stolen had been scared: from me the right to know I had a brother, from Hassan his identity, and from Ali his honor. His nang. His namoos.'(Hosseini, 2003, P.243-244)With his father image of super-ego collapses all of sudden, Amir sets foot on the challenging journey to rescue Hassan's son, Sohrab, from Kabul filled with war, death and terror to end all the liars and betrayals of Amir and his father to the dead Hassan. In the end, Amir's ego forms strongly, realizing his redemption to make him a good man again.

The last but not the least, to some extent the serious racial prejudice also affects Amir's personality development. The concept that the Pashtuns are destined to be superior to the Hazaras and the fact that the Pashtuns in Afghanistan discriminate against and persecute the Hazaras as a matter of course makes it inevitable that Amir as a protagonist have a prejudice against Hazaras when getting along with them in his daily life. "I blew the dust off it, sneaked it into bed with me that night, and was stunned to find an entire chapter on Hazara history. An entire chapter delicated to Hassan's people! In it, I read that my people, the Pashtuns, had persecuted and oppressed the Hazaras. It said the Hazaras had tried to rise against the Pashtuns in the nineteenth century, but the Pashtuns had 'quelled them with unspeakable violence.' ... I did know, like that people called Hazara mice-eating, flat-nosed, load-carrying donkeys. I had heard some of the kids in the neighborhood yell those names to Hassan." (Hosseini, 2003,P.9-10) Although Amir and Hassan drinks the same milk, they takes the first step on the same lawn in the same yard, deep down in Amir's mind, the two can never be friends. Subsequently, Amir is forced to abandon his abundant life in his hometown and move to settle down in America far from the harsh ethnic prejudice of Afghan society completely. However, at the same time, as from a different race from the United States, Amir and other persons from Afghanistan experience invisible or explicit racial discrimination in their daily life. "As for the diaspora, they drift away from their native land to a new country as their temporary home to accept or even adapt to its custom which is completely different from the previous cultural custom. But these persons are hard to abandon their memory of the homeland that belongs to themselves in their deep heart, not to mention their memory of the whole nation. While the physical bodies have a destination, but the spirit of them has no end. This phenomenon seems unsolved dilemma."(Wang Huimin, 2016, P.131) During his stay in America with his father, he realizes what a foolish mistake he made, which is one of the reasons why he dares to face his own mistakes and form his own ego.

\section{CONCLUSION}

In the novel related with the growth of characters, the hero's redemption of his sin is usually realized by the corresponding person's inspiration and instruction, but ultimately it is by the change of his thought and behavior. First, in The Kite Runner, the hero Amir suddenly realizes his unforgettable sin after receiving a phone call from a stranger, and then he fells a deep remorse and a sense of morality in his own heart. It is these urge of positive energy that prompts him to take a decisive decision and determine to return to Afghanistan instantly. The end of this text, Amir yells what Hassan once promised to him sincerely "For you, a thousand times over." to Sohrab. Even though Amir used to hurt Hassan under the drive of the id, he finally forms his own strong ego, facing and making up for his fault, saving himself from the sins and becoming a real life-runner with a sound personality.

Many of us may hurt someone when we were young, like Amir, driven by the id, for the sake of greed or desire. After all, we may lead our life affected by the hidden guilt caused by the sin. However, as long as we dare to face up to our past, make up for it, we will become a really happy person with strong ego embedded in our mind. Even if we can't meet the needs of superego all our lives, we should strive to balance our relationship between the id and ego to live as a strong self with sincerity in our deep heart. A person who can stand up for himself or herself will become a person who can stand up to anything.

\section{REFERENCES}

[1] Calvin Springer Hall. (1987). Freudian Psychology and Western Literature. Bao Huafu,Trans. Changsha: Hunan Art and Literature Press.

[2] Hosseini, Khaled. (2003).The Kite Runner. New York: Berkley Publishing Group Press.

[3] Kate Millett. (2000). Sex politics. Song Wenwei, Trans. Nanjing: Jiangsu People Press.

[4] Shang Biwu.\&Liu Aiping.(2007). Interview with Khaled Hosseini. World Literature Recent, 5, 9-11.

[5] Sigmund Fred. (1933). Introductory lectures on psychoanalysis. Harmondsworth: Penguin books.

[6] Sigmund Fred. (1999). The Interpretation of Dreams. Oxford: Oxford University Press.

[7] Snowden, Ruth. (2006).Teach Yourself Freud. New York: McGraw-Hill Press.

[8] Wang Huimin.\&Jing Zhen. (2016). The Spiritual Watch and Pursuit under the Identity of Diaspora: On the Diaspora Theme and Identity Reconstruction in The Kite Runner. Foreign Languages and Their Teaching, 2, 130-135.

[9] [9Zheng Suhua. (2015). Amir's Personality Growth in The Kite Runner-- Amir's Tripartite Personality Interpreted from Freudian Psychoanalysis. Journal of Nanjing University of Science and Technology (Social Science Edition), 28(01), 73-77. 
Ting Wen was born in Yancheng, China in 1987. She will get postgraduate degree in the year of 2020.

She is currently a postgraduate student in Grade 2 of English and American Literature Major, College of Foreign Studies, Nanjing Agricultural University, Nanjing, China. 